\title{
Erratum: On display on a bug: a systematic approach to characterize antibodies
}

Thomas Knorpp \& Markus F Templin

Nat. Methods 5, 1003-1004 (2008); published online 25 November 2008; corrected after print 26 November 2008.

In the version of this article initially published, Figure 1 was incorrectly described as having been adapted from Rockberry et al. The correct citation is Rockberg et al. The error has been corrected in the HTML and PDF versions of the article.

\section{Erratum: Much room for improvement in deposition rates of expression microarray datasets}

Scott A Ochsner, David L Steffen, Christian J Stoeckert Jr \& Neil J McKenna

Nat. Methods 5, 991 (2008); published online 25 November 2008; corrected after print 26 November 2009.

In the version of this article initially published, the e-mail address of the corresponding author Neil J. McKenna was incorrect. The correct e-mail address should be nmckenna@bcm.edu. The error has been corrected in the HTML and PDF versions of the article. 